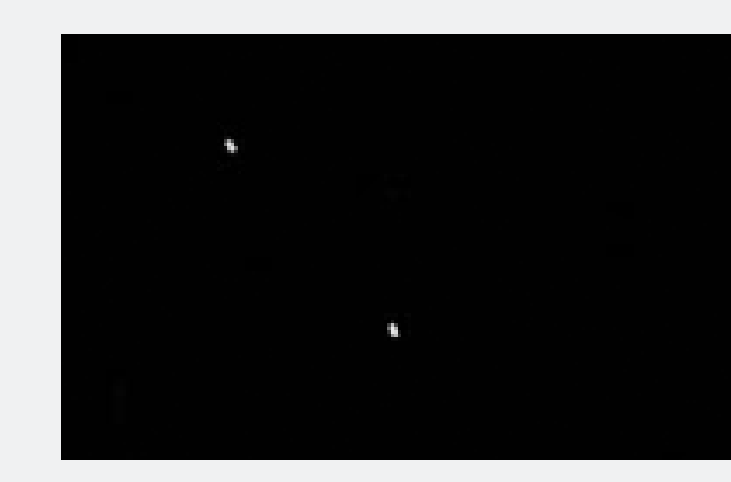

POÉTICAS 


\section{EXPERIMENTOS DE ESCRITA E DESÁGUE - PARA NÃO ENLOUQUECER NA PANDEMIA.}

Carlandréia Ribeiro

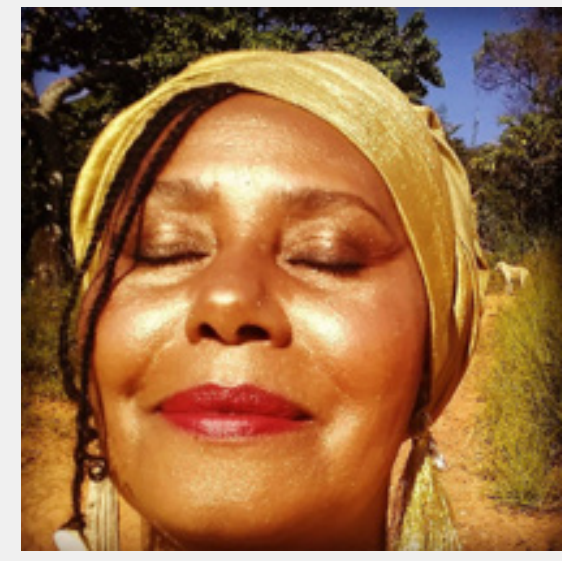

Sou formada em Arte educação pelo MEC, Instituto Pró-Memória e Secretaria Estadual de Educação, atriz, produtora, cantora, coordenadora do FAN - Festival de Arte Negra de Belo Horizonte. Desde 1982, tendo a arte como ferramenta contra o racismo e as desigualdades sociais, tenho participado de importantes momentos sigualdades sociais, tenho participado de importantes momentos dessa luta. Por minhas atuações recebi diversas indicações, tendo sido agraciada com o Prêmio USIMINAS/SINPARC de Melhor Atriz coadjuvante em 2005, "O Segredo de Atlântida". Em 2014 recebi o Prêmio Zumbi de Cultura pelo conjunto de meu trabalho em pro da cultura e da conscientização de jovens no âmbito das artes cênicas e do teatro Negro em Minas Gerais. E em 2016 o Prêmio de Circulação de Espetáculos Cênicos - Prêmio de Artes Cênicas de Minas Gerais - Realizado pelo Governo de Minas Gerais por meio da Secretaria de Estado de Cultura, pelo espetáculo Memórias de Bitita- o coração que não silenciou. Pelo mesmo espetáculo recebi também o Prêmio Leda Maria Martins em 2017.

carlabr6@gmail.com 


\section{O VÍRUS E O VERME}

Era um tempo de visões terríveis.

A morte andava tão cheia de si que não demonstrava nenhum aca nhamento. Ela sorria com seus dentes de ferro e suas mãos manobravam a foice a fiada com tamanha desenvoltura que quase nada escapava.

Nas longas noites de breu ou nos dias cinzentos que se seguiram ela reinou soberana. Tantos homens e tantas mulheres trabalhavam em seu auxílio.

Negavam a dor, pisavam na piedade, debochavam da falta de ar. Trajavam suas vestes de farrapos sangrentos, empunhavam armas sujas, espalhavam calúnias e perfídia e impropérios irrepetíveis.

Nenhuma palavra podia ser dita que trouxesse consolo.

A humanidade que eu ingenuamente um dia cri ser capaz de não repetir suas tragédias, foi nova mente tão vil.

Coroado pelo torpor do ódio, um vírus foi o agente invisível nas mãos do verme, em assombroso encontro entre aqueles que queriam a vida e aqueles que festejavam e dançavam com a morte. 


\section{DEVIR POMBOGIRA}

Fez calhar a vida que eu fosse o meu próprio desassossego

Me converti em confusão

Desacertei o passo

Acertei

Tropecei

E levantei dando gargalhadas na encruzilhada

Se você dobrar a esquina

Cruza comigo

\section{DEVIR OXUM}

Verto em lágrimas a dor

Ofereço em lábios molhados, sinuosos e dados a minha alegria

Escorro lenta por entre as frestas do amor

Me avolumo selvagem arrastando o mundo em enxurrada de fúria

Me trate bem e eu me derreto morna e calmamente

dentro de você 


\section{DEVIR IANSÃ}

A espiral me penetrava por baixo

Por entre as pernas me atravessava o ventre e vazava pelo topo da minha cabeça

Sou uma mulher parida pelo vento

MASSEMBA

Eu vivo aonde nascem os ventos e as tempestades Quando eles chegam até vocês

eles já me atravessaram as víceras e a alma

Mas também é aqui que os primeiros raios de sol se expandem por dentro e por fora do meu corpo

Quando ele chegar em vocês

Eu já estarei alucinada por tanta luz

UM LIVRO PODE SER UM CHARCO DE MEMÓRIAS 
Sobre a mesa as chaves da casa, um amontoado de livros, a xícara com um resto de café que de tão frio já desenha um destino qualquer na borra que se forma no fundo, um cigarro fumegando no cinzeiro lotado.

A última página escrita jaz encharcada de lágrimas. A caneta ainda entre os dedos aguarda pacientemente as dores que ainda não foram impressas no papel.

$--$

Escrevo para me libertar

Toda mulher deveria ter um caderno na ponta dos dedos.

Assisto a espetáculos todas as manhãs. Às maritacas eu devolvo o agrado com risos e uma imitação boba dos seus gritos de alegria do voo. Aos quero-quero eu agradeço pelo nome que eles carregam - quero-quero... desejo, querer, bem-querer é o quero por que quero que essa vida se adiante em liberdade e ca minhos abertos. É para o Senhor dos caminhos abertos, Exu, que eu dou o meu dia. Bato paò para ele diante das montanhas. Ecoa pelo vale o "Asè plantado por ele no fundo da minha garganta." Ta mbém da nço junto com o vento que a travessa por entre as árvores da floresta, Iansã ta mbém mora aqui. 
Aqui, Oyà produz ventos, raios e tempestades. Daqui ela comanda os rumos de quem vazou o véu do tempo.

Nesses espetáculos que me são oferecidos como dádiva, as borboletas de mil cores vêm beijar minha pele. Eu entendo o gesto de delicadeza como um beijo de minha mãe. Tem uma árvore aqui, em especial agrupamento de beleza, pois que se ela já é linda sozinha, agora ela é casa de uma pequenina família de canários que de tão a marelinhos, ganham a parecença de pepitas de ouro com asas.

Eu assisto a tudo em estado de êxtase.

Às vezes eu ando por entre a mata dentro do veio d'água e Oxum vem cochichar nos meus ouvidos. Ela na maioria das vezes diz borbulhando entre as pedras: se o a mor que há em ti não for suficiente. Busque mais a mor. Ah, a voz dela é tão serena e doce! É dentro e profundamente espalhados por cada folha dessa mata que caboclos também vêm sussurrar sobre coisas e dizerem que a gente necessita de prestar atenção ao cuidado. Oxossi, o Rei dessa generosidade em forma de mato, folha, planta e troncos já contou que não anda satisfeito. Eu fiquei com vergonha. Não se machuca um orixá. Eu peço desculpas e Ele me dá o rumo da seta. 
Os espetáculos todos que vejo nas manhãs são o alimento para o dia e para a noite. Toda manhã eu acordo com essa fome de espetáculo, com essa gana de vida.

Nessas manhãs de terça-feira e em todas as outras, é Ogum que me dá a direção da estrada.

Numa manhã de janeiro de 2021

\section{DESCRUZEI O ATLÂNTICO}

Meu corpo vazou a fronteira e rompeu o véu do tempo Em fluxo reverso revi o trajeto dos meus

$\mathrm{Vi}$ a dor escancarada que dilacera a carne

Ouvi os gritos de minha tataravó

Senti o cheiro e a náusea

Fui desfazendo as correntes

Nadei contra as marés e me deparei com o porto da

dolorosa partida

Desfiz todas as voltas em torno da árvore do esquecimento

Matei a desmemória com a força das minhas recordações

O retorno sempre desejado

Estive fora do lugar por uma vida inteira. 
Descruzei o Atlântico e desatei o nó infame que me afastava de mim

\section{HOMEM-VENDAVAL}

Se ao menos eu tivesse ouvido os teus sinais - um estrondo, uma pedra rolando, um raio, um machado descendo do céu. Talvez eu pudesse simular alguma naturalidade diante do espanto da sua chegada.

Tão de rompante, causando refrega nas minhas ideias, desarrumando a vida morna e acostumada que eu levava, virando tudo de ponta cabeça.

E se você for embora do jeito que chegou? Como é que vou me arranjar sem a sua desordem que me faz ter brilho nos olhos, tremer as mãos, que me amolece os joelhos, me seca a boca e me tira o fôlego, que me faz inundar a cama quando me toca com seu fogo?

Perdi todas as telhas do juízo nos braços de um homem-vendaval.

Enqua nto recolho os cacos finjo estar pronta para a próxima tempestade. 


\section{ESPALHADA PELO CONTINENTE}

De um a mor espalhado pelo continente quase morreu uma mulher. Ela ousou percorrer o doce e temível destino de ser água.

Enquanto escorria pelas frestas do caminho não percebeu o desvio que a levava ao precipício. Em vertiginosa queda seu Corpo-líquido bailou em torno daquele Corpo-prazer. Se perdeu no sumidouro dos seus braços.

Qual foi o demônio que o enviou? Ela se perguntava. Se não foi o demônio, por que diabos Deus havia de lhe fazer essa pilhera?

Por que aquele Corpo-prazer aparecer assim, sem ser chamado? Sem que ela estivesse preparada para receber o impacto do mergulho?

O negrume daquele Corpo-prazer, a fartura dos lábios, o olhar que dançava duvidoso entre a esperteza e a dor, a doçura a marga que se podia notar naquela voz rouca quando ele sussurrava nos seus ouvidos.

Uma voz mimada de quem nunca se contentava, de quem sempre queria mais, de quem nunca saciava. 
A mulher se perdeu do seu leito, se afogou em sua própria fluidez, se encharcou daquele Corpo-prazer com tanta sede e tão violenta mente que desmanchou no chão feito poça e esvaiu sugada por toda a terra que havia no continente.

Ele, que não era de nenhuma qualidade de ser liquido, desapareceu. Se desfez de toda a sua solidez de Corpoprazer, sumiu como um meteoro que se desintegra no espaço. Retornou ao pó de onde um dia Deus ou o diabo o deixaram escapar. Ele nunca mais se refez diante dela.

Ela agora recomeça.

De hoje em diante, até quando ela ainda não sabe quando, ela vai se dedicar á tarefa de recolher cada mínima gotícula dessa água de si mesma que se espalhou pelo continente enquanto ela banhava o Corpo-prazer.

Cada gota vem prenhe de lembranças... o negrume do corpo, a fartura dos lábios, os olhos espertos e tristes, a voz rouca doce e a marga - faminta.

Ela recolhe e guarda tudo num lugar escondido dentro da abisal fundura da sua alma. Lá essas memórias ficarão eternas. 
Ela está disposta a se refazer em Corpo-líquido.

Quer ser novamente rio, outra vez jorrar seu gozo, outra vez Corpos-prazer, uma vez mais correr para o mar e morrer de amor espalhada pelo continente.

Nunca fugir do destino de ser água. 